University of Nebraska - Lincoln

DigitalCommons@University of Nebraska - Lincoln

Ultimate Biochemical Oxygen Demand in Semi-Intensively Managed Shrimp Pond Waters

\author{
Bartholomew W. Green \\ USDA, Agricultural Research Service, bart.green@usda.gov
}

George H. Ward

University of Texas at Austin, gward@mail.utexas.edu

Follow this and additional works at: https://digitalcommons.unl.edu/usdaarsfacpub

Part of the Agriculture Commons, and the Aquaculture and Fisheries Commons

Green, Bartholomew W. and Ward, George H., "Ultimate Biochemical Oxygen Demand in Semi-Intensively Managed Shrimp Pond Waters" (2011). Publications from USDA-ARS / UNL Faculty. 2480.

https://digitalcommons.unl.edu/usdaarsfacpub/2480

This Article is brought to you for free and open access by the U.S. Department of Agriculture: Agricultural Research Service, Lincoln, Nebraska at DigitalCommons@University of Nebraska - Lincoln. It has been accepted for inclusion in Publications from USDA-ARS / UNL Faculty by an authorized administrator of DigitalCommons@University of Nebraska - Lincoln. 


\title{
Ultimate biochemical oxygen demand in semi-intensively managed shrimp pond waters
}

\author{
Bartholomew Green ${ }^{\mathrm{a}, *}$, George H. Ward ${ }^{\mathrm{b}}$ \\ a USDA Agricultural Research Service, Stuttgart National Aquaculture Research Center, Stuttgart, AR 72160 USA \\ ${ }^{\mathrm{b}}$ Center for Research in Water Resources, University of Texas at Austin, Austin, TX 78712 USA
}

\section{A R T I C L E I N F O}

\section{Article history:}

Received 29 September 2010

Received in revised form 17 June 2011

Accepted 22 June 2011

Available online 2 July 2011

\section{Keywords:}

Ultimate biochemical oxygen demand

UBOD

Decomposition rate constant

Semi-intensive shrimp culture

Litopenaeus vannamei

\begin{abstract}
A B S T R A C T
Three independent studies were conducted to quantify ultimate biochemical oxygen demand (UBOD) and the corresponding decomposition rate constant for production pond (average 21.5 ha each) waters and effluents on six semi-intensively managed marine shrimp (Litopenaeus vannamei) farms in Honduras. Samples were collected during the rainy season in studies 1-3 and during the dry season only in Study 1 . Pond water samples were collected during the culture period and/or at harvest. The dry season 30-d biochemical oxygen demand $\left(\mathrm{BOD}_{30}\right)$ of pond waters across all farms was $26 \%$ lower and UBOD was $54 \%$ lower, but the decomposition rate constant was more than twice as great as during the rainy season. During the dry season, biochemical oxygen demand was nearly completely expressed after $30 \mathrm{~d}$ of incubation whereas during the rainy season $\mathrm{BOD}$ was about $65 \%$ expressed after $31 \mathrm{~d}$ of incubation and the correlation between $\mathrm{BOD}_{31}$ and UBOD was less strong compared to the dry season. Water quality variables were correlated with measures of BOD during rainy and dry seasons, but only the correlation between chlorophyll $a$ and BOD measures was predictive. In studies 2 and 3, BOD after 88-94 d of incubation was expressed almost completely and corresponded closely with computed UBOD. No significant differences in UBOD were detected in pond samples taken after 30,61, or 71 (harvest) d of grow out in study 3. Mean decomposition rate constant ranged from 0.054 to $0.071 \mathrm{~d}^{-1}$ in studies $1-3$ (rainy season), compared to $0.123 \mathrm{~d}^{-1}$ in Study 1 (dry season).
\end{abstract}

Published by Elsevier B.V.

\section{Introduction}

Pond water and effluent contain a varied mixture of mineral and organic byproducts, including organic carbon compounds, inorganic and organic species of nitrogen, phosphorus, and silicon, both in suspension and solution, as well as a variety of microorganisms. Some of these constituents exert a direct consumption of dissolved oxygen (DO) in chemical reactions, in respiration, or in degradation of complex organics by aerobic and facultative bacteria, while others have an indirect effect on DO by stimulating the growth of photosynthetic and/or heterotrophic organisms in the receiving waters.

One measure of microbiological respiration is the biochemical oxygen demand (BOD), which measures the oxygen consumed in a specified time period per unit volume of water, in the absence of photosynthesis. Briefly, samples of pond effluent initially are saturated with DO and maintained in sealed, dark bottles in a stable laboratory environment, and measurements of DO in the samples are performed at regular intervals. Samples are re-aerated periodically, as necessary, to maintain DO concentrations above $2 \mathrm{mg} \mathrm{L}^{-1}$ (Clesceri et al., 1998).

\footnotetext{
* Corresponding author. Tel.: +1 8706734483.

E-mail addresses: bart.green@ars.usda.gov (B. Green), gward@mail.utexas.edu (G.H. Ward).
}

The DO consumption over time increases rapidly at first then approaches an asymptotic value. This asymptote, termed the ultimate BOD, denoted UBOD, is conceived to be the maximum potential oxygen demand from the labile constituents of the sample. The BOD progression is described by the equation:

$B O D_{t}=\operatorname{UBOD}\left(1-e^{-k t}\right)$

where $B O D_{t}=$ BOD at time $t\left(\mathrm{mg} \mathrm{L}^{-1}\right), U B O D=$ ultimate BOD $\left(\mathrm{mg} \mathrm{L}^{-1}\right)$, $k=$ first-order decomposition rate constant $\left(\mathrm{d}^{-1}\right)$, and $t=$ time, $\mathrm{d}$.

Frequently, BOD is measured in a sample after a specified incubation period, typically 5 days. The resultant BOD value, while informative, does not provide any kinetics information that can be used to estimate how the BOD will be expressed in the receiving water or for modeling purposes (Ward, 1999). Long-term BOD series no longer are performed commonly, and only one study was found in the recent aquaculture literature that quantified UBOD and characterized BOD fractions in channel catfish pond waters (Boyd and Gross, 1999).

Sometimes, for samples high in labile carbon compounds (such as sewage effluent), after the DO depletion appears to have nearly converged to its asymptotic value, a "second stage" reaction begins, typically 58 days after initiation of the incubation, in which the rate of oxygen depletion accelerates then tends asymptotically to a higher value. This 
second stage, or nitrogenous BOD (NBOD), is considered to evidence the activity of nitrifying bacteria, oxidizing ammonia to nitrate. Populations of nitrifying bacteria in diluted samples develop more slowly than heterotrophic bacteria, delaying a measurable oxygen demand from nitrification for 5-8 days (Camp and Meserve, 1974; Tschobanoglous et al., 2003). Consequently, the two-stage oxygen depletion curve often is observed for samples that must be diluted for analysis because the high sample BOD precludes analysis of a concentrated sample.

Semi-intensive shrimp (Litopenaeus vannamei) culture is practiced in many countries in Latin America. Although shrimp production and water quality results frequently are reported for semi-intensive shrimp production research (e.g., Casillas-Hernandez et al., 2006; GuerreroGalván et al., 1999; Martinez-Cordova et al., 2002), BOD seldom is reported. On two semi-intensive shrimp farms studied in Mexico, RuizFernández and Páez-Osuna (2004) reported that pond influent and effluent $\mathrm{BOD}_{2}$ concentrations varied temporally, mean effluent $\mathrm{BOD}_{2}$ was greater, and no seasonal differences were detected. In a study of Honduran semi-intensive shrimp farms, Teichert-Coddington et al. (2000) estimated $\mathrm{BOD}_{5}$ from $\mathrm{BOD}_{2}$ measurements and showed water exchange resulted in a net discharge of $\mathrm{BOD}_{5}$ of $103 \mathrm{~kg} \mathrm{ha}^{-1} 100 \mathrm{~d}^{-1}$. However, we found no published study that evaluated ultimate BOD and the corresponding decomposition rate constant in semi-intensive shrimp pond water.

The objectives of the three studies reported herein were to quantify $\mathrm{BOD}_{5}$ and UBOD, estimate the decomposition rate constant and use these results to evaluate seasonal differences for pond water and effluent on semi-intensive L. vannamei shrimp farms in Honduras. Relationships between water quality variables, production variables and BOD also were investigated. Rainy season shrimp culture in Honduras (May-November) is characterized by lower pond salinity and warmer temperature, and higher yield than for the dry season (Teichert-Coddington and Rodriguez, 1995). During the dry season, many smaller farms in Honduras cease operation while many of the larger farms only fertilize ponds. Therefore, of the three studies we conducted, only study 1 included dry season samples.

\section{Materials and methods}

\subsection{Farm and production characteristics}

Six commercial shrimp farms located in southern Honduras (Department of Choluteca) along estuaries of the Gulf of Fonseca participated in the studies (Fig. 1; Table 1). Shrimp were cultured year-round except for Farm E, which operated only during the rainy season. Farm managers were asked to provide production, water quality, and input data for the entire production cycle for each pond included in each study. Overall, the response rate was high, but some responses were more complete than others and there were exceptions that remained unresolved even after multiple solicitations. Feed conversion ratio (FCR) was calculated as the quotient of total feed fed $(\mathrm{kg})$ divided by the total weight of shrimp harvested. Total nitrogen $(\mathrm{N})$ added as feed was calculated as the product of protein content of the feed and an assumed dry matter content of $90.1 \%$ divided by 6.25 (the average $\mathrm{N}$ content of protein). Fertilizer $\mathrm{N}$ application was calculated as the total application multiplied by the fertilizer $\mathrm{N}$ content.

\subsection{Study 1 and analytical procedures}

In the first study, three to five grow-out ponds ( $19.5 \pm 9.5$ ha; mean $\pm \mathrm{SD}$ ) stocked with $L$. vannamei were sampled during the dry (March) and rainy (June) seasons 2000 on each of four to five shrimp farms located along the El Pedregal, San Bernardo, La Berberia, or La Jagua estuaries, Honduras (Fig. 1). Sampled ponds were at approximately the same stage in the grow-out cycle: day $80( \pm 2)$ of a 92-d $( \pm 4)$ dry-season production cycle, except for Farm D (day 37 of a 113-d production cycle), and day $77( \pm 8)$ of a 113-d $( \pm 15)$ rainyseason production cycle. Samples also were collected from the water supply canal in the vicinity of the ponds sampled, and from three sites each along a 19-23-km section of the El Pedregal estuary and a 40-km section of the San Bernardo estuary. Two consecutive days were required for each season to collect water samples from all farms because of their geographic distribution. Estuarine water samples were collected 1-4 d following pond water sampling.

Water samples were collected using a $90-\mathrm{cm}$ column sampler (Boyd and Tucker, 1992); at least 6 sub-samples were collected at each sample site, pooled, and a 2-L sub-sample was withdrawn for analysis. The water samples were placed on ice in an ice chest and transported to the La Lujosa Water Quality Laboratory, La Lujosa, Choluteca, Honduras. Analysis was initiated 2-6h after sample collection. At the lab, samples were brought to $20 \mathrm{C}$ and salinity was measured using a salinity meter (Model 30, YSI Inc., Yellow Springs, OH USA).

The UBOD protocol (Method 5210C) outlined by Clesceri et al. (1998) was followed. Each sample or dilution water blank was loaded into two BOD bottles $(300 \pm 3 \mathrm{~mL})$. One of each of the paired BOD bottles served as a reservoir of sample used to replace any sample lost during DO measurement and re-oxygenation because the sample adhered to the DO probe or oxygenation tube. Samples in study 1 were diluted based on analyst experience and if phytoplankton abundance was considered high. In the dilution, $200 \mathrm{~mL}$ of sample was mixed in a $500 \mathrm{~mL}$ graduated cylinder with $200 \mathrm{~mL}$ of synthetic seawater of salinity that approximated that of the sample. Synthetic seawater was prepared according to Strickland and Parsons (1972), with modification. Briefly, $310 \mathrm{~g}$ sodium chloride, $100 \mathrm{~g}$ magnesium sulfate heptahydrate, and $0.5 \mathrm{~g}$ sodium carbonate monohydrate were dissolved in 10 L distilled water to yield $35 \%$ o synthetic seawater. The synthetic seawater was diluted with distilled water to obtain lower salinity water. In all three studies no bacterial seed inoculum, BOD nutrient solution, or nitrification inhibitor was used in any sample. Each BOD bottle was wrapped in aluminum foil prior to incubation and the foil wrapping was re-sealed following each DO measurement. All BOD bottles were incubated in the dark in a BOD incubator (Fisher Isotemp, Fisher Scientific, Pittsburgh, PA USA) at $20 \pm 0.5 \mathrm{C}$.

The DO concentration in the sample was measured using a dissolved oxygen meter (Model 52, YSI Inc., Yellow Springs, OH USA) equipped with a polarographic, self-stirring BOD probe (Model 5905, YSI Inc., Yellow Springs, OH USA). Sample DO concentration was increased initially and at each re-oxygenation to $8.3 \pm 0.8 \mathrm{mg} \mathrm{L}^{-1}$ by bubbling filtered, pure oxygen (medical grade) through a plastic tube we perforated with multiple pin holes. Dissolved oxygen in each bottle was measured at 2-4-d intervals with 10-11 measurements beyond the initial measurement being made over the 31-d (dry season) or 30-d (rainy season) incubation period. Samples were re-oxygenated to near saturation whenever the measured DO concentration approached $2 \mathrm{mg} \mathrm{L}^{-1}$. The DO probe and oxygenation tube were rinsed with distilled water and blotted dry between measurements. At each measurement, the DO probe and oxygenation tube were agitated gently before being extracted fully from the mouth of the BOD bottle to shed as much adhered sample as possible. One millimeter of sample from the reservoir BOD bottle was added to the sample bottle to replace any sample lost during DO measurement and re-oxygenation. After DO measurement, the BOD bottle stopper was replaced, excess replacement sample discarded, foil re-sealed, and incubation continued.

In each study, water used for the initial BOD analysis also was analyzed the same day for total ammonia-nitrogen (TAN, phenolhypochlorite method; Strickland and Parsons, 1972). Chlorophyll $a$ was extracted in $90 \%$ acetone from phytoplankton filtered from samples using a $0.45 \mu \mathrm{m}$ pore size glass fiber filter, and concentration in the extract was determined spectroscopically (Strickland and Parsons, 1972). Water samples also were analyzed in study 1 only for total suspended solids (TSS; Clesceri et al., 1998). 

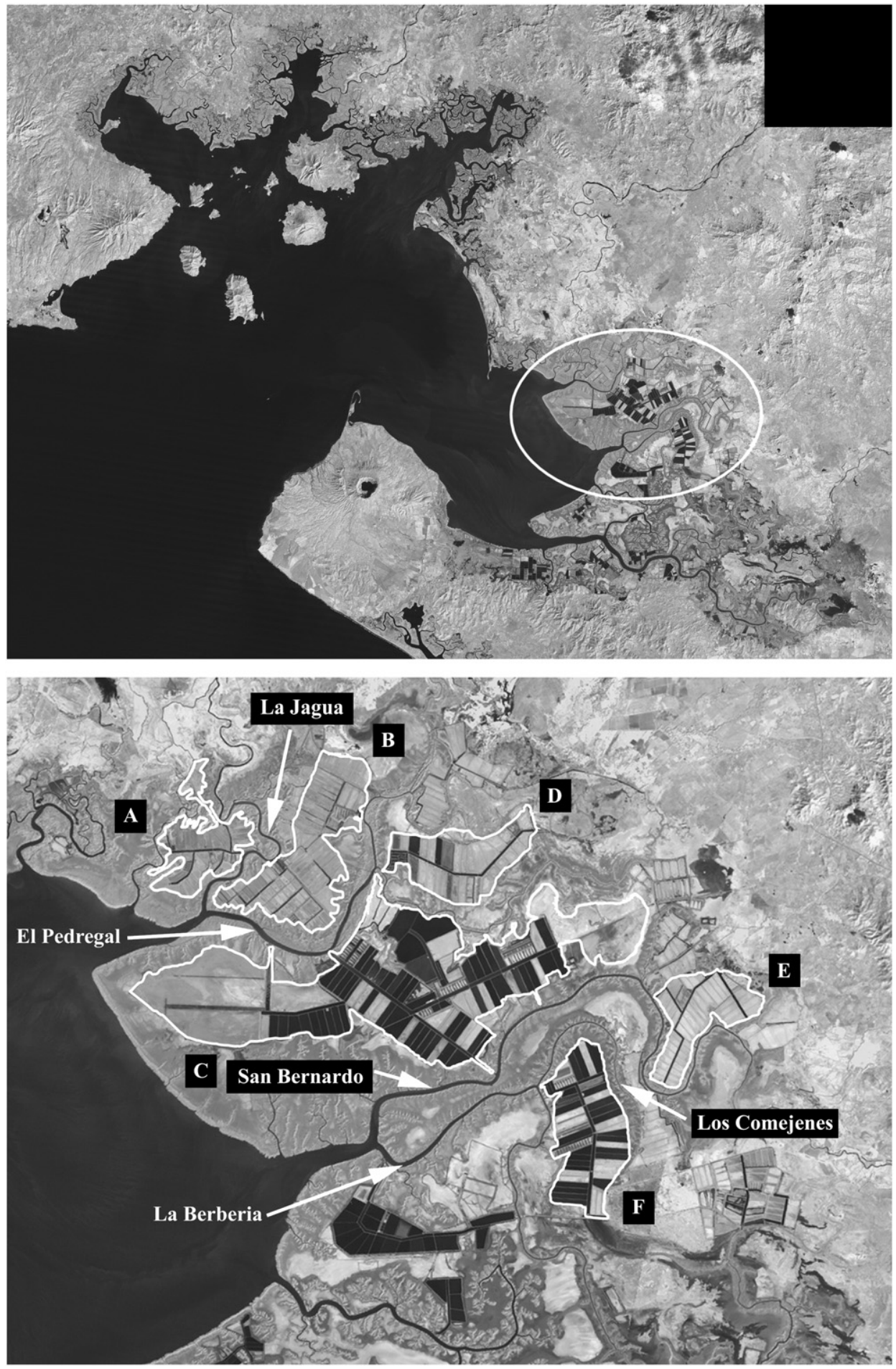

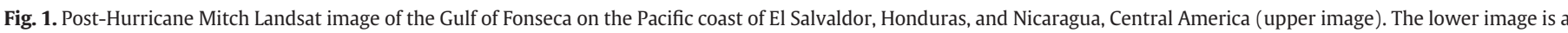

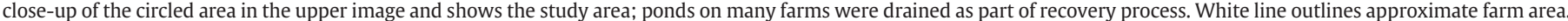
Arrows indicate individual farms and adjacent estuaries. Landsat image courtesy of U.S. Geological Survey.

\subsection{Study 2}

In the second study, a water sample was collected during pond draining in September-October 2001 from one production pond $(22.3 \pm 22.1$ ha; range $8-55$ ha $)$ on each of five farms. Each farm manager was asked to select a production pond they considered to be representative of all the production ponds stocked on their farm during the same general time period. A 2-L water sample was collected from the water entering the drain structure 3-5 h after pond draining was initiated. The sample was placed on ice in an ice chest and transported to the La Lujosa laboratory. Analysis was initiated 2-4 h after sample collection. The same analytical procedure as in Study 1 was used with the following modifications. Each sample was loaded into three BOD bottles; two bottles served as replicate measurements and the third as a sample reservoir. No sample was diluted. Dissolved oxygen in each bottle was measured at 1-2-d intervals during days 1 7, 2-4-d intervals during days 8-14, 3-4-d intervals during days 1576 , and $3-8-d$ intervals during days $77-90$. A total of $28-31$ 
Table 1

Physical data ${ }^{\mathrm{a}}$ on shrimp farms that participated in the studies. Intakes and discharges show the estuarine source of influent and destination of effluent for total farm water use; parenthetical percentages are estimated contributions among multiple estuaries that serve individual farms. The description of each study is given in Sections 2.2.-2.4. Farm locations are shown in Fig. 1.

\begin{tabular}{|c|c|c|c|c|c|}
\hline \multirow[t]{2}{*}{ Farm } & \multirow[t]{2}{*}{ Study } & \multirow{2}{*}{$\frac{\text { Total pond }}{\text { Area (ha) }}$} & \multirow{2}{*}{$\frac{\text { Mean pond }}{\text { Depth }(\mathrm{m})}$} & \multicolumn{2}{|l|}{ Estuarine water } \\
\hline & & & & Intakes & Discharges \\
\hline A & 1,2 & 600 & 1.2 & La Jagua & $\begin{array}{l}\text { La Jagua }(80 \%) \\
\text { El Purgatorio }(20 \%)\end{array}$ \\
\hline B & 1,2 & 904 & 0.7 & La Jagua & El Pedregal \\
\hline C & 1,2 & 3700 & 0.8 & $\begin{array}{l}\text { El Pedregal (67\%) } \\
\text { San Bernardo (33\%) }\end{array}$ & $\begin{array}{l}\text { San Bernardo (50\%) } \\
\text { El Garcero }(40 \%) \\
\text { El Pedregal }(10 \%)\end{array}$ \\
\hline $\mathrm{D}$ & 1,2 & 682 & 0.9 & El Garcero & $\begin{array}{l}\text { El Garcero (50\%) } \\
\text { El Riel }(50 \%)\end{array}$ \\
\hline E & 1,2 & 560 & 1.1 & San Bernardo & $\begin{array}{l}\text { El Quebrachal (70\%) } \\
\text { San Bernardo (30\%) }\end{array}$ \\
\hline $\mathrm{F}$ & 3 & 1002 & 1.1 & La Berberia & $\begin{array}{l}\text { La Berberia (50\%) } \\
\text { Los Comejenes (50\%) }\end{array}$ \\
\hline
\end{tabular}

a Sources: Boyd et al., 2001; Ward and Green, 2001, unpublished report; Green, 2004, unpublished data.

measurements beyond the initial measurement were made over the 90-d incubation period.

\subsection{Study 3}

In the third study, one farm manager was asked to select two production ponds $(22.7 \pm 0.4 \mathrm{ha})$ that were stocked contemporaneously and were representative of all production ponds stocked on the farm during the same general time period. Water samples were collected from each of the two ponds and from the adjacent water supply canal as in Study 1 during the production cycle and as in Study 2 during pond draining. Water samples were collected 30 and $61 \mathrm{~d}$ after stocking and at harvest (70-72 $\mathrm{d}$ post-stock). The same analytical procedure as in Study 1 was used with the following modifications. Each sample was loaded into three BOD bottles; as in Study 2, one bottle served as a sample reservoir and the other two as replicates. No sample was diluted. Dissolved oxygen in each bottle was measured at 1-2-d intervals from days $1-7,1-4-d$ intervals from day 8 through days 49-60, and 3-7-d intervals from days 50-61 through days 88-94. A total of 24-31 measurements beyond the initial measurement were made over the 88-94-d incubation period.

\subsection{Calculation of BOD load}

The BOD load to estuaries from the average-sized pond on each farm was estimated based on pond management information, UBOD and incremental UBOD for a water exchange event and for pond draining during the rainy and dry seasons. Incremental UBOD was the increase in pond BOD attributable to shrimp culture (i.e., the difference between pond or drain water BOD and supply canal water BOD); supply canal water was used as a proxy for estuarine water since we did not have estuarine water samples taken at each farm's pump station. The mean water exchange for all studies $\left(5.5 \% \mathrm{~d}^{-1}\right)$ was used as the exchange rate for Farm A (because of differences between Studies 1 and 2) and Farm E (because of no response from farm manager). We assumed for this calculation that the average UBOD per farm represented the actual UBOD in exchange event and draining waters. Pond draining was completed over a 24 48-h period (Boyd et al., 2001).

\subsection{Data analyses}

All data analyses were performed using SAS version 9.1.3 (SAS Institute, Cary, NC). The SAS NLIN procedure was used to model UBOD as measured by our time-series incubations, by solving simultaneously for UBOD and $k$ assuming the nonlinear regression relation, $B O D_{t}=U B O D\left(1-e^{-k t}\right)$, where $B O D_{t}$ denotes the cumulative $\mathrm{O}_{2}$ depletion at day $t$. Full datasets (88-94-d incubation) and restricted datasets (30-35-d incubation) from Studies 2 and 3 were used to model total BOD to compare outcomes. The correlation procedure was used to evaluate correlation among water quality and production variables for Study 1. Mixed models repeated measures analysis of variance with compound symmetry covariance structure was used to analyze water quality variables over time for Study 3. Differences among least squares means were evaluated using the DIFF option with the Tukey adjustment of $P$ values in SAS.

\section{Results}

\subsection{Farm production characteristics}

Semi-intensive production techniques used by the farms in this study were characterized by low stocking rates (range: $7-22 \mathrm{PL} / \mathrm{m}^{-2}$ ), low input utilization, and low yields (range: $100-716 \mathrm{~kg} \mathrm{ha}^{-1}$, dry season; $350-777 \mathrm{~kg} \mathrm{ha}^{-1}$, rainy season; Table 2). Shrimp were fed a formulated ration (20-25\% protein) on all farms during the rainy season and only on one farm during the dry season. Otherwise, chemical fertilizer was the only nutrient input to ponds, often added only during the first weeks of the culture period during the rainy and dry seasons. Water exchange was used during the culture cycle to manage pond water quality; no farm utilized mechanical aerators. While most farm managers reported a water exchange rate, fewer provided detailed water exchange data. Water exchange frequency and rate, and cumulative water exchange varied among farms.

\subsection{Study 1 water quality and BOD}

Low TAN and chlorophyll a concentrations characterized dry season water quality in estuarine, supply canal, and pond samples (Table 3). While TAN also was low in rainy season samples, chlorophyll a concentration was higher in supply canal and pond samples (Table 3 ). Total suspended solids decreased from estuarine to supply canal to pond samples during both seasons. A representative DO consumption curve for a pond during the rainy season study is shown in Fig. 2. Salinity varied little from estuary to supply canal to pond during the dry season, whereas during the rainy season salinity increased linearly. Observed $\mathrm{BOD}_{5}$ in ponds averaged 8.6 and $7.7 \mathrm{mg} \mathrm{L}^{-1}$ during the dry and rainy seasons, respectively, while the corresponding $\mathrm{BOD}_{30-31}$ means were 20.1 and $27.2 \mathrm{mg} \mathrm{L}^{-1}$, respectively. The ratio of $\mathrm{BOD}_{5}: \mathrm{BOD}_{30-31}$ averaged 0.43 during the dry season and 0.30 during the rainy season. Mean $\mathrm{BOD}_{30-31}$ in estuarine water was 15.7 and $13.4 \mathrm{mg} \mathrm{L}^{-1}$ during the dry and rainy seasons, respectively. Computed UBOD during the dry and rainy seasons averaged 15.9 and 17.1 , and 19.2 and $42.1 \mathrm{mg} \mathrm{L}^{-1}$ in estuarine and pond samples, respectively. The decomposition rate constant, $k$, for ponds averaged $0.123 \mathrm{~d}^{-1}$ and $0.057 \mathrm{~d}^{-1}$ during the dry and rainy seasons, respectively.

Strong positive correlations were observed among all BOD estimates during the dry season, and $\mathrm{BOD}_{5}$ was highly predictive of $\mathrm{BOD}_{30}$ or UBOD (Table 4). Water quality variables (TAN, chlorophyll $a$, and TSS) also were positively correlated with dry season BOD estimates, but only chlorophyll $a$ was predictive of BOD. There also were positive correlations among TSS and chlorophyll $a$ and TAN. No correlations were detected during the dry season among any variable and cumulative feed addition or cumulative $\mathrm{N}$ addition. Dry season estimated shrimp biomass was negatively correlated with water quality variables, but no correlation was strong enough to be predictive.

During the rainy season, $\mathrm{BOD}_{5}$ was positively correlated with $\mathrm{BOD}_{31}$, but was not correlated with UBOD (Table 4). There was a positive correlation between $\mathrm{BOD}_{31}$ and $\mathrm{UBOD}$, but the correlation 
Table 2

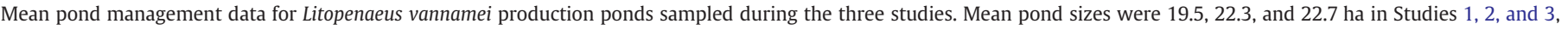
respectively.

\begin{tabular}{|c|c|c|c|c|c|c|c|c|c|}
\hline \multirow[t]{2}{*}{ Location } & \multirow[t]{2}{*}{ Season } & \multirow{2}{*}{$\begin{array}{l}\text { Culture } \\
\text { Duration } \\
\text { (d) }\end{array}$} & \multicolumn{2}{|l|}{ Feed } & \multirow[b]{2}{*}{ FCR } & \multirow{2}{*}{ 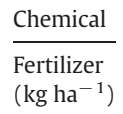 } & \multicolumn{3}{|c|}{ Water exchange } \\
\hline & & & $\begin{array}{l}\text { Daily } \\
\left(\mathrm{kg} \mathrm{ha}^{-1} \mathrm{~d}^{-1}\right)\end{array}$ & $\begin{array}{l}\text { Total } \\
\left(\mathrm{kg} \mathrm{ha}^{-1}\right)\end{array}$ & & & $\begin{array}{l}\text { Rate } \\
\left(\% d^{-1}\right)\end{array}$ & $\begin{array}{l}\text { Events } \\
\text { (d) }\end{array}$ & $\begin{array}{l}\text { Cumulative } \\
\left(\mathrm{m}^{3} \mathrm{ha}^{-1}\right)\end{array}$ \\
\hline \multicolumn{10}{|l|}{ Study 1} \\
\hline \multirow[t]{2}{*}{ Farm A } & Dry & 89 & 0 & 0 & 0 & 17 & 3.1 & $\mathrm{a}$ & $\mathrm{a}$ \\
\hline & Rainy & 105 & a & 186 & 0.6 & 13 & 2.7 & a & $\mathrm{a}$ \\
\hline \multirow[t]{2}{*}{ Farm B } & Dry & 101 & 0 & 0 & 0 & 97 & 0.9 & 9 & 9000 \\
\hline & Rainy & 92 & 8.0 & 253 & 0.5 & 89 & 1.3 & 14 & 12,167 \\
\hline \multirow[t]{2}{*}{ Farm C } & Dry & 93 & 0 & 0 & 0 & 132 & 6.6 & 7 & 3650 \\
\hline & Rainy & 110 & 8.0 & 312 & 1.4 & 136 & 4.4 & 7 & 2417 \\
\hline \multirow[t]{2}{*}{ Farm D } & Dry & 113 & 6.3 & 529 & 1.2 & 18 & 4.0 & $\mathrm{a}$ & a \\
\hline & Rainy & 109 & 7.2 & 598 & 1.5 & 19 & 4.0 & a & $\mathrm{a}$ \\
\hline \multirow[t]{2}{*}{ Farm E } & Dry & & Does not operate & & & & & & \\
\hline & Rainy & 139 & 11.5 & 538 & 0.8 & 0 & a & $\mathrm{a}$ & $\mathrm{a}$ \\
\hline \multicolumn{10}{|l|}{ Study 2} \\
\hline Farm A & Rainy & 122 & 9.6 & 1173 & 2.8 & 6.8 & 15.3 & 44 & 85,888 \\
\hline Farm B & Rainy & 89 & 7.6 & 674 & 3.0 & 23.2 & 5.0 & 13 & 6825 \\
\hline Farm C & Rainy & 101 & 10.0 & 1008 & 14.8 & 14.7 & 9.0 & 23 & 15,250 \\
\hline Farm D & Rainy & a & $\mathrm{a}$ & a & $\mathrm{a}$ & 29.3 & $\mathrm{a}$ & $\mathrm{a}$ & a \\
\hline Farm E & Rainy & 106 & 3.7 & 365 & 2.2 & 9.6 & a & $\mathrm{a}$ & a \\
\hline \multicolumn{10}{|l|}{ Study 3} \\
\hline Farm F & Rainy & 72 & 11.9 & 603 & 1.4 & 25.7 & 2.0 & 14 & 2724 \\
\hline
\end{tabular}

a Data not reported.

was not strong enough to be predictive. Rainy season water quality variables were positively correlated with BOD estimates, but only the correlation between chlorophyll $a$ and $\mathrm{BOD}_{31}$ was strong enough to be predictive. The cumulative feed addition was positively correlated with $\mathrm{BOD}_{31}$ and chlorophyll $a$ concentration. No correlation was detected for cumulative $\mathrm{N}$ addition and any variable except for $\mathrm{BOD}_{5}$. Estimated shrimp biomass was positively correlated with cumulative feed addition.

\subsection{Study 2 water quality and BOD}

The selected pond at each farm was drained on average after a 104-d culture period. Mean TAN and chlorophyll $a$ concentrations were $0.05 \mathrm{mg} \mathrm{L}^{-1}$ and $102.1 \mathrm{mg} \mathrm{m}^{-3}$, respectively (Table 5). Mean coefficient of variation for measured DO concentrations for replicate samples at each time period was low and averaged 3.1\%. The mean $\mathrm{BOD}_{5}$ was $10.4 \mathrm{mg} \mathrm{L}^{-1}$ and the mean $\mathrm{BOD}_{90}$ and UBOD were 37.1 and $36.7 \mathrm{mg} \mathrm{L}^{-1}$, respectively. The $\mathrm{BOD}_{5}$ : $\mathrm{BOD}_{90}$ ratio averaged 0.29 . The decomposition rate constant averaged $0.054 \mathrm{~d}^{-1}$. There was a linear relationship between computed UBOD and $\mathrm{BOD}_{5}\left(R^{2}=0.671\right)$ in pond water.

\subsection{Study 3 water quality and BOD}

Mean TAN and chlorophyll $a$ concentrations in ponds did not differ significantly by sample date, but salinity increased significantly over time (Table 6). Mean coefficient of variation for measured DO concentrations for replicate samples at each time period was low and averaged 2.6\%. A representative DO consumption curve for replicate pond and canal samples is shown in Fig. 2. The mean $\mathrm{BOD}_{5}$ : $\mathrm{BOD}_{88-94}$ ratio was 0.35 . The $\mathrm{BOD}_{5}$ for the harvest sample was significantly lower than for the 30- and 61-d samples, which did not differ. Pond $\mathrm{BOD}_{88-94}$ for the harvest and 61-d samples was significantly lower than for the 30-d sample. Computed UBOD, however, did not differ significantly among sample dates, and averaged $61.30 \mathrm{mg} \mathrm{L}^{-1}$. The mean decomposition rate constant was $0.071 \mathrm{~d}^{-1}$. The computed UBOD and $\mathrm{BOD}_{5}$ in pond water were linearly related $\left(R^{2}=0.899\right)$. The increment in BOD that resulted from shrimp culture was calculated using the water supply canal BOD because no estuarine BOD data was available. The water supply canal
BOD at day 61 , which was higher than for the pond likely because of the high phytoplankton biomass, was not used in calculating incremental BOD. After $30 \mathrm{~d}$ of culture, incremental BOD $_{88}$ was $57.8 \mathrm{mg} \mathrm{L}^{-1}$, but at harvest (70-72 d of culture) incremental BOD $_{94}$ was $39.7 \mathrm{mg} \mathrm{L}^{-1}$.

\subsection{Restricted versus full dataset analysis}

Computed UBOD based on the restricted dataset (see Section 2.6) underestimated by $2-31 \%$ the computed UBOD based on the complete dataset. Mean computed UBOD was $14 \%$ lower for the restricted dataset compared to the full dataset. The decomposition rate constant for the restricted dataset was up to two times larger than for the full dataset and averaged 45\% higher.

\subsection{BOD loads}

The estimated UBOD load discharged during an exchange event from an average-sized pond averaged 148 and $331 \mathrm{~kg} \mathrm{~d}^{-1}$ for the dry and rainy seasons, respectively (Table 7 ). The corresponding incremental UBOD means were 93 and $150 \mathrm{~kg} \mathrm{~d}^{-1}$, respectively. Discharge during the two-day pond draining for harvest added a UBOD load to the estuary that averaged 1604 and $4144 \mathrm{~kg} \mathrm{~d}^{-1}$ during the dry and rainy seasons, respectively. Incremental UBOD at pond draining discharged to the estuary a mean of 937 and $1924 \mathrm{~kg} \mathrm{~d}^{-1}$ during the dry and rainy seasons, respectively.

\section{Discussion}

The BOD progression in Study 1 during the dry season was distinct from that of the rainy season. During the dry season, mean BOD across all farms after 30-31 d incubation was 26\% lower than the rainy season, UBOD was 54\% lower, and the decomposition rate constant was more than twice as great. Oxidation of the labile organic matter nearly was complete after $30 \mathrm{~d}$ of incubation during the dry season given the close correspondence of $\mathrm{BOD}_{30}$ and UBOD and the high correlation between $\mathrm{BOD}_{5}, \mathrm{BOD}_{30}$, and $\mathrm{UBOD}$, whereas during the rainy season $\mathrm{BOD}$ was about $65 \%$ expressed after $31 \mathrm{~d}$ of incubation and the correlation between $\mathrm{BOD}_{31}$ and UBOD was weaker. 
Table 3

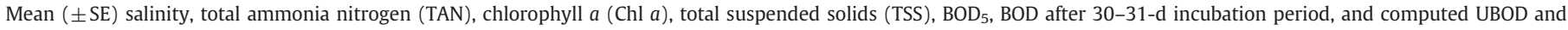

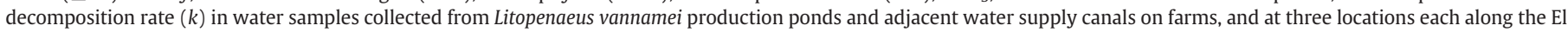
Pedregal and San Bernardo estuaries during Study 1.

\begin{tabular}{|c|c|c|c|c|c|c|c|c|}
\hline \multirow[t]{2}{*}{ Location } & \multirow{2}{*}{$\begin{array}{l}\text { Salinity } \\
\left(\mathrm{g} \mathrm{L}^{-1}\right)\end{array}$} & \multirow{2}{*}{$\begin{array}{l}\text { TAN } \\
\left(\mathrm{mg} \mathrm{L}^{-1}\right)\end{array}$} & \multirow{2}{*}{$\begin{array}{l}\text { Chl } a \\
\left(\mathrm{mg} \mathrm{m}^{-3}\right)\end{array}$} & \multirow{2}{*}{$\begin{array}{l}\text { TSS } \\
\left(\mathrm{mg} \mathrm{L}^{-1}\right)\end{array}$} & \multirow{2}{*}{$\begin{array}{l}\mathrm{BOD}_{5} \\
\left(\mathrm{mg} \mathrm{L}^{-1}\right)\end{array}$} & \multirow{2}{*}{$\begin{array}{l}\mathrm{BOD}_{\mathrm{t}} \\
\left(\mathrm{mg} \mathrm{L}^{-1}\right)\end{array}$} & \multicolumn{2}{|l|}{ Computed } \\
\hline & & & & & & & $\begin{array}{l}\text { UBOD } \\
\left(\mathrm{mg} \mathrm{L}^{-1}\right)\end{array}$ & $\begin{array}{l}k \\
\left(d^{-1}\right)\end{array}$ \\
\hline \multicolumn{9}{|l|}{ Dry season } \\
\hline El Pedregal $^{2}$ & $32.5 \pm 0.3$ & $0.42 \pm 0.25$ & $37.7 \pm 2.4$ & $479.5 \pm 302.2$ & $10.3 \pm 0.2$ & $23.2 \pm 1.6$ & $23.0 \pm 2.2$ & $0.109 \pm 0.009$ \\
\hline San Bernardo ${ }^{2}$ & $36.4 \pm 0.7$ & $0.02 \pm 0.01$ & $13.0 \pm 4.7$ & $103.2 \pm 34.1$ & $3.1 \pm 0.3$ & $8.2 \pm 1.1$ & $8.7 \pm 1.2$ & $0.072 \pm 0.007$ \\
\hline \multicolumn{9}{|l|}{ Farm A } \\
\hline Canal $^{1}$ & $30.6 \pm 0.2$ & $0.18 \pm 0.04$ & $15.5 \pm 4.6$ & $79.6 \pm 1.8$ & $2.6 \pm 0.4$ & $7.3 \pm 0.2$ & $8.0 \pm 0.2$ & $0.072 \pm 0.012$ \\
\hline Pond $^{3}$ & $33.7 \pm 0.9$ & $0.02 \pm 0.01$ & $20.5 \pm 5.2$ & $13.8 \pm 4.0$ & $4.7 \pm 0.7$ & $11.3 \pm 1.2$ & $11.4 \pm 1.1$ & $0.114 \pm 0.008$ \\
\hline \multicolumn{9}{|l|}{ Farm B } \\
\hline Canal $^{1}$ & $30.7 \pm 0.8$ & $0.08 \pm 0.05$ & $3.9 \pm 2.3$ & $9.2 \pm 0.8$ & $1.7 \pm 0.2$ & $6.2 \pm 0.3$ & $7.0 \pm 0.0$ & $0.058 \pm 0.009$ \\
\hline Pond $^{3}$ & $32.0 \pm 0.5$ & $0.04 \pm 0.00$ & $27.3 \pm 12.3$ & $7.7 \pm 2.5$ & $5.5 \pm 1.8$ & $14.4 \pm 4.3$ & $13.9 \pm 4.0$ & $0.109 \pm 0.009$ \\
\hline \multicolumn{9}{|l|}{ Farm C } \\
\hline Canal $^{1}$ & $30.7 \pm 0.5$ & $0.11 \pm 0.00$ & $18.6 \pm 5.7$ & $46.7 \pm 16.5$ & $2.7 \pm 0.2$ & $7.6 \pm 0.5$ & $8.5 \pm 0.7$ & $0.064 \pm 0.001$ \\
\hline Pond ${ }^{4}$ & $35.4 \pm 0.7$ & $0.12 \pm 0.01$ & $89.5 \pm 23.0$ & $29.1 \pm 3.5$ & $12.8 \pm 2.5$ & $29.5 \pm 5.9$ & $29.6 \pm 5.2$ & $0.127 \pm 0.030$ \\
\hline \multicolumn{9}{|l|}{ Farm D } \\
\hline Canal $^{1}$ & $30.5 \pm 0.2$ & $0.10 \pm 0.01$ & $21.4 \pm 7.8$ & $14.8 \pm 5.2$ & $4.1 \pm 1.0$ & $9.5 \pm 0.8$ & $8.9 \pm 0.5$ & $0.102 \pm 0.026$ \\
\hline Pond $^{3}$ & $30.2 \pm 0.3$ & $0.08 \pm 0.01$ & $38.2 \pm 12.1$ & $25.2 \pm 6.4$ & $11.5 \pm 2.0$ & $22.6 \pm 3.0$ & $21.8 \pm 2.9$ & $0.141 \pm 0.026$ \\
\hline \multicolumn{9}{|l|}{ Rainy season } \\
\hline El Pedregal $^{2}$ & $6.8 \pm 2.0$ & $0.16 \pm 0.03$ & $29.1 \pm 3.7$ & $37.6 \pm 8.5$ & $5.7 \pm 0.3$ & $17.5 \pm 2.0$ & $22.6 \pm 3.8$ & $0.052 \pm 0.007$ \\
\hline San Bernardo 2 & $23.2 \pm 5.9$ & $0.14 \pm 0.05$ & $20.8 \pm 2.8$ & $43.5 \pm 19.4$ & $2.9 \pm 0.4$ & $9.2 \pm 1.4$ & $11.6 \pm 2.1$ & $0.058 \pm 0.006$ \\
\hline \multicolumn{9}{|l|}{ Farm A } \\
\hline Canal $^{1}$ & $14.7 \pm 0.5$ & $0.05 \pm 0.03$ & $114.7 \pm 32.3$ & $59.1 \pm 29.9$ & $11.4 \pm 0.2$ & $25.5 \pm 0.3$ & $25.5 \pm 0.4$ & $0.104 \pm 0.007$ \\
\hline Pond $^{2}$ & $29.3 \pm 0.7$ & $0.06 \pm 0.03$ & $118.9 \pm 36.9$ & $23.7 \pm 0.5$ & $7.7 \pm 1.2$ & $35.4 \pm 5.0$ & $73.1 \pm 6.4$ & $0.023 \pm 0.003$ \\
\hline \multicolumn{9}{|l|}{ Farm B } \\
\hline Canal $^{1}$ & $9.6 \pm 0.2$ & $0.12 \pm 0.03$ & $48.5 \pm 9.1$ & $16.7 \pm 0.5$ & $4.9 \pm 0.5$ & $13.6 \pm 0.3$ & $15.4 \pm 0.2$ & $0.063 \pm 0.004$ \\
\hline Pond $^{2}$ & $25.7 \pm 3.4$ & $0.06 \pm 0.02$ & $56.8 \pm 1.0$ & $14.9 \pm 2.1$ & $8.1 \pm 0.6$ & $22.6 \pm 1.2$ & $23.9 \pm 1.1$ & $0.083 \pm 0.005$ \\
\hline \multicolumn{9}{|l|}{ Farm C } \\
\hline Canal $^{1}$ & $26.9 \pm 8.4$ & $0.13 \pm 0.01$ & $55.8 \pm 22.2$ & $17.7 \pm 5.7$ & $8.3 \pm 1.3$ & $19.6 \pm 1.2$ & $20.3 \pm 0.2$ & $0.078 \pm 0.020$ \\
\hline Pond $^{2}$ & $38.9 \pm 1.7$ & $0.09 \pm 0.01$ & $56.6 \pm 19.9$ & $11.8 \pm 2.9$ & $8.4 \pm 1.0$ & $18.6 \pm 1.8$ & $19.0 \pm 1.2$ & $0.094 \pm 0.003$ \\
\hline \multicolumn{9}{|l|}{ Farm D } \\
\hline Canal $^{1}$ & $17.7 \pm 0.4$ & $0.10 \pm 0.00$ & $93.0 \pm 4.5$ & $20.8 \pm 7.3$ & $5.2 \pm 0.7$ & $21.3 \pm 5.2$ & $27.0 \pm 8.4$ & $0.057 \pm 0.010$ \\
\hline Pond $^{2}$ & $22.4 \pm 0.6$ & $0.09 \pm 0.02$ & $163.0 \pm 11.9$ & $17.3 \pm 4.9$ & $9.6 \pm 1.2$ & $38.1 \pm 4.2$ & $51.3 \pm 6.4$ & $0.050 \pm 0.009$ \\
\hline \multicolumn{9}{|l|}{ Farm E } \\
\hline Canal $^{1}$ & $32.0 \pm 1.2$ & $0.07 \pm 0.03$ & $32.2 \pm 1.4$ & $8.4 \pm 1.2$ & $7.9 \pm 0.6$ & $18.3 \pm 5.4$ & $21.4 \pm 9.8$ & $0.100 \pm 0.059$ \\
\hline Pond $^{2}$ & $35.7 \pm 0.7$ & $0.11 \pm 0.03$ & $48.5 \pm 3.1$ & $14.3 \pm 1.7$ & $4.8 \pm 1.9$ & $21.4 \pm 1.1$ & $43.3 \pm 8.4$ & $0.034 \pm 0.016$ \\
\hline
\end{tabular}

$\mathrm{t}=31 \mathrm{~d}$ (dry season); $30 \mathrm{~d}$ (rainy season).

$1 \mathrm{~N}=2$.

$2 \mathrm{~N}=3$.

$3 \mathrm{~N}=4$.

$4 \mathrm{~N}=5$.

Phytoplankton biomass, as indicated by chlorophyll $a$, is the major source of organic matter in aquaculture ponds (Boyd, 1973) and was highly correlated with $\mathrm{BOD}_{30}$ and UBOD during the dry season, but only with $\mathrm{BOD}_{31}$ during the rainy season. Perhaps pond water organic

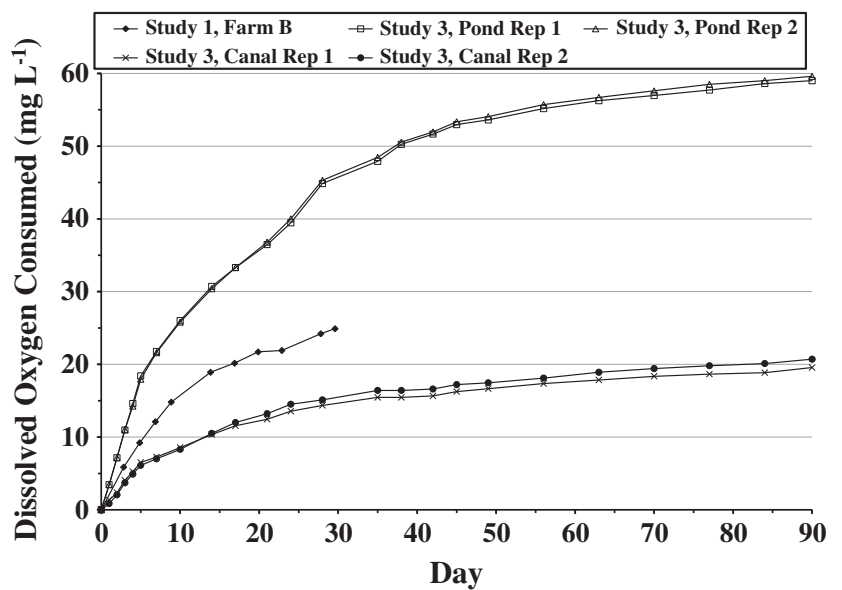

Fig. 2. Representative dissolved oxygen depletion curves for a pond water sample during the Study 1 rainy season, and from replicate pond and water supply canal samples during Study 3. matter during the dry season was more labile than during the rainy season, which combined with the lower dry season mean chlorophyll a concentration resulted in BOD being expressed almost fully after $30 \mathrm{~d}$. The substantially higher dry-season estuarine TSS supports this explanation, although support could be stronger had we analyzed for total volatile solids as well. The higher decomposition rate constant and $\mathrm{BOD}_{5}: \mathrm{BOD}_{30}$ ratio during the dry season indicates that pond organic matter was more labile. During the rainy season when mean estuarine TSS was low and mean pond chlorophyll a concentration was high, pond organic matter likely was dominated by phytoplankton, which was slower to decompose completely.

Nitrification likely was contemporaneous with organic matter oxidation as we did not discern a distinct NBOD in the BOD progression. Since only $38 \%$ of our samples were diluted (1:2 dilution only in Study 1 ), adequate numbers of nitrifying bacteria likely were present from the start of incubation. Samples with established populations of nitrifying bacteria do not exhibit a two-stage BOD progression (Tschobanoglous et al., 2003). Boyd and Gross (1999) noted that BOD in catfish ponds, where organic matter predominantly was phytoplankton, is expressed slowly with a decomposition rate constant of about 0.06 , which is similar to the mean rate constant we observed during the rainy season. Boyd and Gross (1999) also noted that in their samples NBOD, which originated in part from high pond TAN (mean $=1.4 \mathrm{mg} \mathrm{L}^{-1}$ ) and $\mathrm{N}$ in the BOD nutrient dilution solution, contributed significantly to UBOD. In the present study, TAN concentrations in pond and supply canal waters 
Table 4

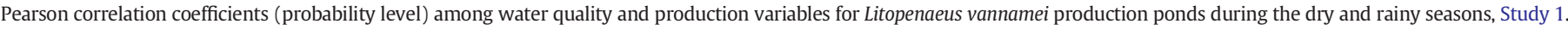

\begin{tabular}{|c|c|c|c|c|c|c|c|c|c|}
\hline \multirow[t]{2}{*}{ Variable } & \multicolumn{9}{|l|}{ Variable $^{a}$} \\
\hline & $\mathrm{BOD}_{5}$ & $\mathrm{BOD}_{30 / 31}$ & UBOD & TSS & Chl $a$ & TAN & Cum Feed & Cum N & Biomass \\
\hline \multicolumn{10}{|l|}{ Dry season } \\
\hline $\mathrm{BOD}_{5}$ & 1.00 & & & & & & & & \\
\hline $\mathrm{BOD}_{30}$ & $0.924(<0.001)$ & 1.000 & & & & & & & \\
\hline UBOD & $0.880(<0.001)$ & $0.989(<0.001)$ & 1.000 & & & & & & \\
\hline TSS & $0.585(0.014)$ & $0.620(0.008)$ & $0.684(0.003)$ & 1.000 & & & & & \\
\hline Chl $a$ & $0.830(<0.001)$ & $0.944(<0.001)$ & $0.950(<0.001)$ & $0.593(0.012)$ & 1.000 & & & & \\
\hline TAN & $0.621(0.008)$ & $0.634(0.006)$ & $0.678(0.003)$ & 0.615 (0.009) & $0.588(0.013)$ & 1.000 & & & \\
\hline Cum Feed & $0.304(0.236)$ & $0.145(0.580)$ & $0.123(0.639)$ & $0.281(0.274)$ & $-0.099(0.707)$ & $0.157(0.548)$ & 1.000 & & \\
\hline Cum N & $-0.174(0.505)$ & $-0.040(0.880)$ & $0.063(0.809)$ & $0.193(0.459)$ & $0.077(0.769)$ & 0.335 (0.189) & $-0.263(0.308)$ & 1.000 & \\
\hline Biomass & $-0.397(0.115)$ & $-0.425(0.089)$ & $-0.473(0.055)$ & $-0.628(0.007)$ & $-0.436(0.080)$ & $-0.464(0.060)$ & $-0.301(0.240)$ & $-0.108(0.681)$ & 1.000 \\
\hline \multicolumn{10}{|c|}{ Rainy season } \\
\hline $\mathrm{BOD}_{5}$ & 1.000 & & & & & & & & \\
\hline $\mathrm{BOD}_{31}$ & $0.562(0.036)$ & 1.000 & & & & & & & \\
\hline UBOD & $-0.072(0.808)$ & $0.724(0.003)$ & 1.000 & & & & & & \\
\hline TSS & $0.255(0.401)$ & $0.725(0.005)$ & $0.755(0.003)$ & 1.000 & & & & & \\
\hline Chl $a$ & $0.492(0.074)$ & $0.913(<0.001)$ & $0.597(0.024)$ & $0.517(0.070)$ & 1.000 & & & & \\
\hline TAN & $-0.597(0.031)$ & $-0.389(0.189)$ & $-0.127(0.680)$ & $-0.470(0.123)$ & $-0.208(0.496)$ & 1.000 & & & \\
\hline Cum Feed & $0.462(0.096)$ & $0.588(0.027)$ & $0.122(0.678)$ & $0.066(0.829)$ & $0.706(0.005)$ & $0.065(0.834)$ & 1.000 & & \\
\hline Cum N & $0.574(0.032)$ & $0.053(0.857)$ & $-0.456(0.101)$ & $-0.362(0.224)$ & $0.060(0.839)$ & $-0.037(0.904)$ & $0.448(0.108)$ & 1.000 & \\
\hline Biomass & $0.214(0.463)$ & $0.406(0.149)$ & $0.120(0.682)$ & $0.111(0.717)$ & $0.426(0.129)$ & $-0.052(0.867)$ & $0.787(0.001)$ & $0.196(0.502)$ & 1.000 \\
\hline
\end{tabular}

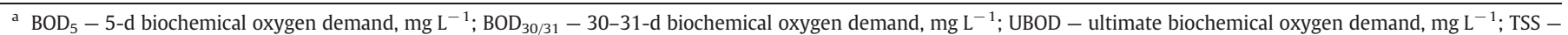

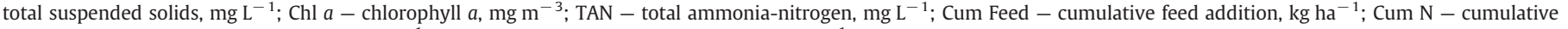
nitrogen addition as feed and fertilizer, $\mathrm{kg} \mathrm{ha}^{-1}$; Biomass - estimated shrimp biomass, $\mathrm{kg} \mathrm{ha}^{-1}$.

were low (mean $<0.2 \mathrm{mg} \mathrm{L}^{-1}$ ) and no BOD nutrient dilution solution was used.

The BOD after 88-94 d incubation in Studies 2 and 3 was expressed almost completely and corresponded closely with computed UBOD, except for the study 330 -d sample where computed UBOD underestimated $\mathrm{BOD}_{88}$ by $11 \%$ on average, likely because individual measurements during the 88-d incubation period were somewhat more variable among sample dates. The absence of significant differences among study 3 sample dates in UBOD, TAN, and chlorophyll a concentrations probably resulted from the small number of replicates. Mean chlorophyll $a$ concentration in ponds at harvest decreased $40 \%$ compared to samples taken less than 2 weeks earlier, possibly because of a die off. Phytoplankton biomass varies throughout the culture cycle in aquaculture ponds and can experience a sudden, unexplained population die off (Boyd et al., 1978).

In all but the rainy season of Study $1, \mathrm{BOD}_{5}$ could be used to estimate UBOD. However, the utility of this relationship depends on the strength of the correlation, and, moreover, provides no information on the rate at which effluent constituents are assimilated.

The highest $\mathrm{BOD}_{5}$ observed during the present studies was $25.8 \mathrm{mg} \mathrm{L}^{-1}$ for an exchange water sample and $17.7 \mathrm{mg} \mathrm{L}^{-1}$ for a drain water sample. The majority (86\%) of exchange water samples had a $\mathrm{BOD}_{5}$ less than $20 \mathrm{mg} \mathrm{L}^{-1}$ and $100 \%$ of the drain water samples had a $\mathrm{BOD}_{5}$ less than $20 \mathrm{mg} \mathrm{L}^{-1}$. Seasonal differences in $\mathrm{BOD}_{5}$ also were observed during study 1: $94 \%$ of dry season values were less than

Table 5

Mean salinity, total ammonia nitrogen (TAN), chlorophyll $a(\mathrm{Chl} a), \mathrm{BOD}_{5}, \mathrm{BOD}_{90}$, and computed UBOD and decomposition rate $(k)$ in water samples collected during pond draining from one Litopenaeus vannamei production pond (average 22.3 ha) on each of 5 farms during Study 2.

\begin{tabular}{|c|c|c|c|c|c|c|c|}
\hline \multirow[t]{2}{*}{ Location } & \multirow{2}{*}{$\begin{array}{l}\text { Salinity } \\
\left(\mathrm{g} \mathrm{L}^{-1}\right)\end{array}$} & \multirow{2}{*}{$\begin{array}{l}\text { TAN } \\
\left(\mathrm{mg} \mathrm{L}^{-1}\right)\end{array}$} & \multirow{2}{*}{$\begin{array}{l}\text { Chl } a \\
\left(\mathrm{mg} \mathrm{m}^{-3}\right)\end{array}$} & \multirow{2}{*}{$\begin{array}{l}\mathrm{BOD}_{5} \\
\left(\mathrm{mg} \mathrm{L}^{-1}\right)\end{array}$} & \multirow{2}{*}{$\begin{array}{l}\text { BOD }_{90} \\
\left(\mathrm{mg} \mathrm{L}^{-1}\right)\end{array}$} & \multicolumn{2}{|l|}{ Computed } \\
\hline & & & & & & $\begin{array}{l}\text { UBOD } \\
\left(\mathrm{mg} \mathrm{L}^{-1}\right)\end{array}$ & $\begin{array}{l}k \\
\left(\mathrm{~d}^{-1}\right)\end{array}$ \\
\hline Farm A & 6.8 & 0.10 & 43.3 & 7.9 & 24.0 & 23.7 & 0.057 \\
\hline Farm B & 17.4 & a & 341.2 & 12.2 & 60.6 & 60.6 & 0.046 \\
\hline Farm C & 8.9 & 0.02 & 54.2 & 8.6 & 35.9 & 35.6 & 0.048 \\
\hline Farm D & 6.7 & 0.06 & 55.7 & 15.9 & 38.9 & 36.6 & 0.080 \\
\hline Farm E & 14.6 & 0.00 & 15.9 & 7.3 & 26.2 & 26.9 & 0.041 \\
\hline
\end{tabular}

a Sample lost.
$20 \mathrm{mg} \mathrm{L}^{-1}$, whereas $100 \%$ of rainy season values were less than $12 \mathrm{mg} \mathrm{L}^{-1}$. These are higher than values reported for catfish ponds, for which $90 \% \mathrm{BOD}_{5}$ values were less than $8.0 \mathrm{mg} \mathrm{L}^{-1}$ and no $\mathrm{BOD}_{5}$ exceeded $17.2 \mathrm{mg} \mathrm{L}^{-1}$ (Boyd and Gross, 1999). All BOD 5 concentrations measured during the present studies were less than the $30 \mathrm{mg} \mathrm{L}^{-1} \mathrm{BOD}_{5}$ standard proposed for Best Aquaculture Practices (Boyd, 1999, 2003).

The semi-diurnal tide (period $12.4 \mathrm{~h}$ ) in the El Pedregal and San Bernardo estuaries exhibits a high tidal range (ca. $3 \mathrm{~m}$ ) and large tidal excursion (ca. $10 \mathrm{~km}$ or more). Consequently, these channel estuaries are intensely mixed systems characterized by high TSS that limits sunlight penetration and results in low primary productivity, as indicated by chlorophyll a concentrations. Sediments settled out and phytoplankton biomass increased when estuarine water was pumped into shrimp farm water supply canals where water current was very low. During the dry season, BOD in canal water was slightly lower than in estuarine water likely because as TSS settled out in the supply canal some phytoplankton may have flocculated (Avnimelech et al., 1982). During the rainy season, estuarine TSS concentrations were lower and phytoplankton was less likely to flocculate. Consequently, supply canal chlorophyll $a$ concentration and BOD were higher than in estuarine waters.

Chlorophyll $a$ and BOD concentrations increased once supply canal water was introduced into production ponds and fertilization and feeding were initiated. Rainy season estimated BOD loads to the estuaries as a result of water exchange and pond draining were higher than during the dry season and reflect seasonal differences in pond management and water quality among farms. We feel our assumption that the average UBOD per farm was representative of all exchange events and pond draining was reasonable. This would be strengthened if a greater number of UBOD determinations were made on each farm through time for exchange events and pond draining. Our assumption that pond effluent UBOD was similar throughout the pond draining process was supported by Teichert-Coddington et al. (2000) who showed no significant differences in semi-intensive shrimp pond effluent $\mathrm{BOD}_{2}$ as pond volume decreased from $100 \%$ to $0 \%$. Additionally, Teichert-Coddington et al. (1999) reported no significant difference in $\mathrm{BOD}_{5}$ of effluent from intensively managed $L$. vannamei ponds as pond volume decreased from $100 \%$ to $4 \%$ full. The $\mathrm{BOD}_{5}$ of the final $4 \%$ of pond volume was significantly greater than the $\mathrm{BOD}_{5}$ for samples taken when 
Table 6

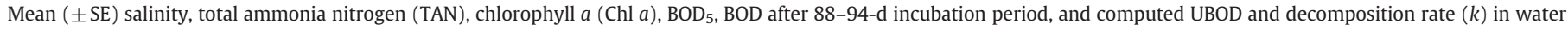
samples collected from two production ponds and the adjacent water supply canal on Farm F during Study 3.

\begin{tabular}{|c|c|c|c|c|c|c|c|}
\hline \multirow[t]{2}{*}{ Location } & \multirow{2}{*}{$\begin{array}{l}\text { Salinity } \\
\left(\mathrm{g} \mathrm{L}^{-1}\right)\end{array}$} & \multirow{2}{*}{$\begin{array}{l}\text { TAN } \\
\left(\mathrm{mg} \mathrm{L}^{-1}\right)\end{array}$} & \multirow{2}{*}{$\begin{array}{l}\text { Chl } a \\
\left(\mathrm{mg} \mathrm{m}^{-3}\right)\end{array}$} & \multirow{2}{*}{$\begin{array}{l}\mathrm{BOD}_{5} \\
\left(\mathrm{mg} \mathrm{L}^{-1}\right)\end{array}$} & \multirow{2}{*}{$\begin{array}{l}\mathrm{BOD}_{\mathrm{t}} \\
\left(\mathrm{mg} \mathrm{L}^{-1}\right)\end{array}$} & \multicolumn{2}{|l|}{ Computed } \\
\hline & & & & & & $\begin{array}{l}\text { UBOD } \\
\left(\mathrm{mg} \mathrm{L}^{-1}\right)\end{array}$ & $\begin{array}{l}k \\
\left(\mathrm{~d}^{-1}\right)\end{array}$ \\
\hline \multicolumn{8}{|c|}{ 30-d sample } \\
\hline Canal $^{1}$ & 11.6 & 0.18 & 29.6 & 5.2 & 18.7 & 18.2 & 0.055 \\
\hline Pond $^{2}$ & $14.5 \pm 0.3 c$ & $0.06 \pm 0.03 a$ & $181.5 \pm 1.5 \mathrm{a}$ & $25.8 \pm 0.3 \mathrm{a}$ & $76.5 \pm 0.9 \mathrm{a}$ & $68.1 \pm 2.6 \mathrm{a}$ & $0.073 \pm 0.004$ \\
\hline \multicolumn{8}{|c|}{ 61-d sample } \\
\hline Canal $^{1}$ & 22.4 & 0.06 & 186.0 & 19.9 & 63.5 & 61.6 & 0.060 \\
\hline Pond $^{2}$ & $20.8 \pm 0.1 b$ & $0.03 \pm 0.01 \mathrm{a}$ & $190.3 \pm 33.9 \mathrm{a}$ & $24.4 \pm 1.6 \mathrm{a}$ & $59.9 \pm 3.5 b$ & $57.1 \pm 3.3 \mathrm{a}$ & $0.084 \pm 0.006$ \\
\hline \multicolumn{8}{|c|}{ Harvest sample } \\
\hline Canal $^{1}$ & 24.8 & 0.03 & 56.0 & 6.3 & 20.2 & 19.1 & 0.056 \\
\hline Pond $^{2}$ & $23.2 \pm 0.1 \mathrm{a}$ & $0.00 \pm 0.00 a$ & $114.6 \pm 112.2 \mathrm{a}$ & $17.7 \pm 0.6 \mathrm{~b}$ & $59.9 \pm 0.5 b$ & $58.7 \pm 0.1 \mathrm{a}$ & $0.056 \pm 0.005$ \\
\hline
\end{tabular}

$\mathrm{t}=88 \mathrm{~d}$ (30-d sample); $92 \mathrm{~d}$ (61-d sample); $94 \mathrm{~d}$ (harvest sample).

${ }^{1} \mathrm{~N}=1$.

${ }^{2} \mathrm{~N}=2$.

abc: Pond means within column followed by the same letter did not differ significantly $(P>0.05)$.

ponds were 100,40 , or $20 \%$ full. A large percentage of the shrimp harvest occurs when the pond is nearly empty and shrimp activity as they exit the pond stirs up sediments.

Shrimp pond effluent contained a moderate phytoplankton biomass. Our results and those of Boyd and Gross (1999) indicated that the BOD was expressed slowly in pond waters where phytoplankton was the dominant form of organic matter. Phytoplankton in effluent is unlikely to die en masse upon entering estuarine waters, unless there is a large difference in salinity. Some phytoplankton can survive in the estuary, but the constant mixing and low light levels will limit productivity. Phytoplankton is unlikely to flocculate in the main estuarine channel because of the current, but as the tide floods the mangrove root system the water current no longer will be sufficient to maintain algal-clay flocs in suspension. However, quantification of this process and its impact on estuarine oxygen budgets would require substantial effort.

Estuarine water used in these studies to fill ponds initially and for water exchange was not pristine, but rather contained a moderate amount of UBOD that was transferred through the farm and contributed to the UBOD of farm effluent. Incremental UBOD can be substantial, comprising up to $56 \%$ of drain water UBOD during the rainy season and up to $71 \%$ during the dry season. However interesting it is to estimate the incremental UBOD, the effluent UBOD at the farm discharge point will impact the receiving waters and is the quantity of interest to regulatory authorities. Thus, prudent

Table 7

Estimated UBOD load discharged to the estuary from the average-sized pond ${ }^{1}$ on each farm per water exchange event and at pond draining for harvest during the rainy and dry seasons. Incremental UBOD is the increase in pond UBOD that results from shrimp culture. Pond draining takes two days. No dry season data were available for farm F.

\begin{tabular}{|c|c|c|c|c|}
\hline \multirow[t]{2}{*}{ Location } & \multicolumn{2}{|c|}{ Exchange event } & \multicolumn{2}{|c|}{ Pond draining } \\
\hline & $\begin{array}{l}\text { UBOD } \\
\left(\mathrm{kg} \mathrm{d}^{-1}\right)\end{array}$ & Incremental UBOD & UBOD & Incremental UBOD \\
\hline \multicolumn{5}{|c|}{ Rainy season } \\
\hline Farm A & 601 & 349 & 5466 & 3169 \\
\hline Farm B & 96 & 52 & 1507 & 806 \\
\hline Farm C & 289 & 50 & 2157 & 372 \\
\hline Farm D & 377 & 163 & 4716 & 2040 \\
\hline Farm E & 285 & 130 & 2587 & 1178 \\
\hline Farm F & 337 & 159 & 8428 & 3976 \\
\hline \multicolumn{5}{|c|}{ Dry season } \\
\hline Farm A & 64 & 19 & 1025 & 307 \\
\hline Farm B & 11 & 6 & 631 & 311 \\
\hline Farm C & 343 & 244 & 2601 & 1851 \\
\hline Farm D & 173 & 102 & 6160 & 1278 \\
\hline Farm E & \multicolumn{4}{|c|}{ Does not operate } \\
\hline
\end{tabular}

${ }^{1}$ Farm A, 15 ha; farm B, 13 ha; farm C, 22 ha; farm D, 22 ha; farm E, 12 ha; farm F, 25 ha. and appropriate use of chemical fertilizers, close management of feeding rates, and use of water exchange in response to management criteria rather than as a routine practice are steps that can be implemented to manage effluent UBOD. Additional reduction of effluent BOD by $60-70 \%$ can be achieved by holding pond effluent in a settling pond for 6-12 h prior to final discharge into receiving waters (Teichert-Coddington et al., 1999).

The UBOD together with the applicable kinetic rate constant are used to model the effect of an oxygen-demanding organic on the dissolved oxygen of a watercourse into which it is discharged, after the dilution of the organic load is taken into account. Recommended methodology for quantifying UBOD calls for a 20-60-d sample incubation period (Clesceri et al., 1998; Tschobanoglous et al., 2003). The BOD progression, depending upon the concentration of decomposable organic matter in the sample, may approach asymptotically the UBOD within $30 \mathrm{~d}$, as we observed during the study 1 dry season. Or the BOD still may be increasing, albeit at a much slower rate, after $30 \mathrm{~d}$ of incubation as it was for the study 1 rainy season samples. The BOD measured after 30-31 d of incubation approximated the computed UBOD only $40 \%$ of the time. When we modeled UBOD using study 2 and 3 restricted datasets (first 30-35 days of incubation), the computed UBOD underestimated the computed UBOD from the full (88-94-d incubation period) datasets by a mean of $14 \%$. And, the decomposition rate constant for the restricted dataset was up to two times larger than for the full dataset and averaged $45 \%$ higher. This indicates that the longer incubation time is especially important for accurately quantifying kinetic rates. Boyd and Gross (1999) noted that phytoplankton appears to die slowly during the 30$\mathrm{d}$ incubation period and observed a layer of green phytoplankton on the bottom of BOD bottles after $5 \mathrm{~d}$ of incubation. Ammonification of dead organic $\mathrm{N}$ will continue to supply TAN for nitrification for some time after all living organic matter dies. Thus, when UBOD and $k$ for semi-intensively managed $L$. vannamei production ponds must be quantified, especially for modeling the impact of pond effluents on receiving water DO concentrations, we recommend that undiluted samples be incubated and re-oxygenated frequently during incubation, that no nitrification inhibitor or nutrients be added, and that samples be incubated for $90 \mathrm{~d}$.

\section{Acknowledgments}

We thank the farm managers and support personnel for their cooperation and assistance during these studies. We thank the Associación Nacional de Acuicultores de Honduras (ANDAH) for its support of this study. We thank Lic. Delia Martinez, Laboratorio de Calidad de Agua, La Lujosa, Choluteca, Honduras, for performing the water quality and BOD analyses. Partial funding for study 1 was 
B. Green, G.H. Ward / Aquaculture 319 (2011) 253-261

261

provided through the Auburn University-U. S. Geological Survey Cooperative Agreement 00CRA0010 to the senior author while at Auburn University. Mention of trade names or commercial products in this article is solely for the purpose of providing specific information and does not imply recommendation or endorsement by the U.S. Department of Agriculture.

References

Avnimelech, Y., Toreger, B.W., Reed, L.W., 1982. Mutual flocculation of algae and clay: evidence and implications. Science 216, 63-65.

Boyd, C.E., 1973. Summer algal communities and primary productivity in fish ponds. Hydrobiologia 41, 357-390.

Boyd, C.E., 1999. Codes of Practice for Responsible Shrimp Farming. Global Aquaculture Alliance, St Louis, MO. 42 pp.

Boyd, C.E., 2003. Guidelines for aquaculture effluent management at the farm-level. Aquaculture 226, 101-112.

Boyd, C.E., Gross, A., 1999. Biochemical oxygen demand in channel catfish Ictalurus punctatus pond waters. Journal of the World Aquaculture Society 30, 349-356.

Boyd, C.E., Tucker, C.S., 1992. Water quality and pond soil analyses for aquaculture. Alabama Agricultural Experiment Station, Auburn University, AL. 183 pp.

Boyd, C.E., Davis, J.A., Johnston, E., 1978. Die-offs of the blue-green alga, Anabaena variabilis, in fish ponds. Hydrobiologia 61, 129-133.

Boyd, C.E., Haws, M.C., Green, B.W., 2001. Improving shrimp mariculture in Latin America: good management practices (GPs) to reduce environmental impacts and improve efficiency of shrimp aquaculture in Latin America and an assessment of practices in the Honduran shrimp industry. Coastal Resources Center, University of Rhode Island, Narragansett, RI. 88 pp.

Camp, T.R., Meserve, R.L., 1974. Water and Its Impurities, Second Edition. Dowden, Hutchinson and Ross, Inc, Stroudsburg, PA. 384 pp.

Casillas-Hernandez, R., Magallon-Barajas, F., Portillo-Clarck, G., Paez-Osuna, F., 2006. Nutrient mass balances in semi-intensive shrimp ponds from Sonora, Mexico using two feeding strategies: trays and mechanical dispersal. Aquaculture 258, 289-298.
Clesceri, L.S., Greenberg, A.E., Eaton, A.D., 1998. Standard methods for the examination of water and wastewater, 20th edition. American Public Health Association, Washington, D.C. 1,237 pp.

Guerrero-Galván, S.R., Páez-Osuna, F., Ruiz-Fernández, A.C., Espinoza-Angulo, R., 1999. Seasonal variation in the water quality and chlorophyll $a$ of semi-intensive shrimp ponds in a subtropical environment. Hydrobiologia 391, 33-45.

Martinez-Cordova, L.R., Campaña-Torres, A., Porchas-Cornejo, M.A., 2002. The effects of variation in feed protein level on the culture of white shrimp, Litopenaeus vannamei (Boone) in low-water exchange experimental ponds. Aquaculture Research 33, 995-998.

Ruiz-Fernández, A.C., Páez-Osuna, F., 2004. Comparative survey of the influent and effluent water quality of shrimp ponds on Mexican farms. Water Environment Research 76, 5-14.

Strickland, J.D.H., Parsons, T.R., 1972. A Practical Handbook of Seawater Analysis, Bulletin 167Second Edition. Fisheries Research Board of Canada, Ottawa, Canada. $310 \mathrm{pp}$.

Teichert-Coddington, D.R., Rodriguez, R., 1995. Semi-intensive commercial grow-out of Penaeus vannamei fed diets containing differing levels of crude protein during wet and dry seasons in Honduras. Journal of the World Aquaculture Society 26, 72-79.

Teichert-Coddington, D.R., Rouse, D.B., Potts, A., Boyd, C.E., 1999. Treatment of harvest discharge from intensive shrimp ponds by settling. Aquacultural Engineering 19, 147-161.

Teichert-Coddington, D.R., Martinez, D., Ramirez, E., 2000. Partial nutrient budgets for semi-intensive shrimp farms in Honduras. Aquaculture 190, 139-154.

Tschobanoglous, G., Burton, F.L., Stensel, H.D., 2003. Wastewater Engineering: Treatment and Reuse, Metcaff \& Eddy, Inc, Fourth Edition. McGraw-Hill, New York, NY. 1,819 pp.

Ward, G.H., 1999. Analysis of Honduran shrimp farm impacts on channel estuaries of the Gulf of Fonseca. In: McElwee, K., Burke, D., Niles, M., Erna, H. (Eds.), Sixteenth Annual Technical Report: Pond Dynamics/Aquaculture CRSP, Oregon State University, Corvallis, OR, pp. 115-119. http://pdacrsp.oregonstate.edu/pubs/ technical/16tch/8hr2-2.pdf. accessed 31 August 2010.

Ward, G.H., Green, B.W., 2001. Effects of shrimp farming on the water quality of El Pedregal and San Bernardo estuaries. Golfo de Fonseca, Honduras. Project Final Report, USGS Activity B7, Auburn University-USGS Cooperative Agreement 00CRA0010, Auburn University, AL. 148 pp. (Unpublished report). 